УДК 633.179:631.53.01:631.559, DOI 10.31210/visnyk2018.04.13

(C) 2018

Кулик М. І., кандидат сільськогосподарських наук,

Рожко I. I., здобувач

(науковий керівник - кандидат сільськогосподарських наук М. І. Кулик)

Полтавська державна аграрна академія

\title{
ЗАКОНОМІРНОСТІ ФОРМУВАННЯ УРОЖАЙНОСТІ НАСІННЯ ПРОСА ПРУТОПОДІБНОГО В УМОВАХ ЛІСОСТЕПУ УКРАЇНИ
}

\section{Рецензент - доктор сільськогосподарських наук, професор Г. П. Жемела}

Акиентовано увагу на необхідності дослідження особливостей формування урожайності насіння проса прутоподібного (світчграсу) для забезпечення виробничих площ достатньою кількістю насіннєвого матеріалу. Здійснено спроуа визначення залежності урожаю насіння від елементів технології вирощування у зв'язку з погодними умовами вететаційного періоду. Експеримент із вивчення насіннєвої продуктивності світчграсу проведено в умовах Лісостепу з використанням методичних рекомендацій вітчизняних та зарубіжних авторів. За результати дослідження визначено комплексний вплив елементів технології вирощування на фоні контрастних умов вететаціі культури на урожайність насіння світчграсу. Встановлено, щуо на урожайність насіння світчграсу мають вплив погодні умови вирощування (середньодобова температура повітря та кількість опадів) протягом вететаційного періоду. Найбільша урожайність насіння формується за вирощуванні рослин за ширини міжряддя 60 см, Як ширші, так $і$ вужчі міжряддя зменшують даний показник. Визначено рівнозначний вплив біометричних показників рослин (висоти та кількості стебел) на урожайність насіння світчграсу. При изьому застосування весняного підживлення посівів певною мірою нівелює негативний вплив погодних умов.

Ключові слова: просо прутоподібне, кількісні показники рослин, урожайність, насіння, закономірності.

Постановка проблеми. На сьогоднішній день в Україні головними пріоритетами нової галузі біоенергетики - $€$ пошук шляхів здешевлення різних видів рослинної сировини, удосконалення існуючої технології вирощування енергетичних культур, формування необхідної інфраструктури для переробки біомаси і отримання рідкого, газоподібного та твердого біопалива. Залучення біопалива до використання у ПЕК (паливоенергетичний комплекс) нашої країни дасть змогу здешевити вартість енергії у різних сферах, розвинути економіку, добробут територіальних громад та поліпшити екологію довкілля.

Проблематичним питанням залишається доступність та якість насіннєвого та посадкового матеріалу для закладки нових енергоплантацій на маргінальних землях. У науковій літературі не в повній мірі висвітлено технологію вирощування енергетичних культур задля отримання насіння, шляхи підвищення урожайності насіння та поліпшення посівних кондицій насіннєвого та садивного матеріалу. Все це й зумовило актуальність дослідження.

Аналіз основних досліджень і публікацій, у яких започатковано розв'язання проблеми. Просо прутоподібне (світчграс) інтенсивно досліджується за кордоном для всебічного використання: на біопаливо, для тваринництва, використання у паперовій промисловості та ін. [22]. В Україні переважна кількість публікації стосується вивчення закономірностей формування урожайності біомаси світчграсу на біопаливні цілі.

Під час вивчення світчграсу в Україні було встановлено, що в урожайність культури в Лівобережно-Дніпровській провінції формується за рахунок вмісту сухої речовини у фітомасі, густоти стеблостою, довжини прапорцевого листка, висоти рослин та ін. Для умов ДністровськоДніпровської провінції встановлена інша закономірність формування продуктивності світчграсу: висота рослин - довжина прапорцевого листка - кількість стебел та інші, менш значимі показники [1].

Визначено, що в умовах України просо прутоподібне має високу стійкість до вилягання та ураження хворобами і шкідниками, середню морозостійкість та високу посухостійкість. Розпочинаючи 3 третього року, біомаса може збиратись на біопаливні та насіннєві цілі $[3,4,10]$.

Найбільшу урожайність біомаси в умовах Лісостепу забезпечують сорти світчграсу третього року вегетації: Кейв-ін-рок (11,6 т/га), Форесбург $(11,7$ т/га) і Картадж $(10,9$ т/га) за ширини міжряддя 45 см другого строку сівби. Визначено, що урожайність на 46,7-72,9\% залежить від строку сівби, на 13,6-29,9 \% - від ширини міжряддя і на 12,7-22,7 \% - від їх взаємодії [6]. 


\section{СІЛЬСЬКЕ ГОСПОДАРСТВО. РОСЛИННИЦТВО}

Автором встановлено, що урожайність світчграсу залежить від строку сівби, що має зв'язок i3 використанням вологи грунту рослинами у разі вирощування їх за ширини міжряддя 45 см [11].

Згідно $з$ висновками L. E. Moser i K. P. Vogel [13], основними факторами, які визначають територію пристосування сорту, є реакція на довжину світлового дня, кількість опадів та вологість. Збільшення тривалості світлового дня призведе до фази цвітіння на початку літа. Коли на одному місці вирощуються різні сорти, північні екотипи виростають нижчими, в них раніше настає фаза цвітіння та дозрівання, ніж у південних. Також значно менше буде отримано біомаси, порівняно 3 південними екотипами.

M. Sanderson iз співавторами [16] порівняли вихід сухої маси та дозрівання. Найбільший вихід був у сорту Кейв-ін-рок (понад 12 тонн сухої речовини), період дозрівання - 135 діб; а найменший - у Dacotah (понад 6 тонн сухої речовини), період дозрівання - менше 100 діб.

Тому для проведення досліджень нас зацікавив саме сорт Кейв-ін-рок, оскільки на території України рослини цього сорту пройдуть усі етапи органогенезу, сформують насіння до закінчення вегетаційного період, та забезпечать значну кількість сухої речовини для виробництва біопалива [8].

Застосування добрив у підживлення насіннєвих посівів світчграсу залишається ще не 3'ясованим. Визначено лише потреби рослин окремих генотипів світчграсу в азоті, фосфорі та калію для використання на біопаливні цілі [16].

Дослідження, проведені Samuel B. McLaughlin, Lynn Adams Kszos [15], дали змогу встановити, що скорочення прогнозованих витрати на виробництво світчграсу на $25 \%$ досягається за рахунок підвищення урожайності культури, на 50 \% - за рахунок вибору кращих, регіонально адаптованих сортів; шляхом оптимізації частоти та часу збору; шляхом зниження норми внесення азоту (40 \%).

Turnhollow et al. встановили, що для вирощування біомаси та насіння потреба рослин світчграсу в азоті становить лише 50 кг на гектар [19]. Для американських Великих рівнин рекомендації щодо норми внесення азотних добрив надаються лише для світчграсу, який вирощується для випасання худоби. Залежно від кількості опадів норми внесення азоту коливаються між 50 і 100 кг на гектар на територіях, відповідно, з 450 і 750 мм опадів на рік [23].

K. Vogel визначив, що для укорінених посівів світчграсу найкращим принципом для внесення азотних добрив, можливо, є внесення в нормі, екві- валентній коефіцієнту отримання урожаю, який становить близько 6-10 кг на тонну сухої речовини для осіннього урожаю і 4-8 - для весняного [20].

Поряд із цим R. Samson встановив, що вирощування світчграсу на менш родючих грунтах потребує внесення азоту більше рекомендованої норми на $25 \%$. [14].

Більшість досліджень із вивчення фосфорних дорив доводять, що світчграс не реагує на фосфор, навіть на малопродуктивних грунтах $[17,18]$.

Таким чином, вибір сорту залежить від довготи, на якій будуть розташовані посіви. Сорти, які походять із Південної Америки, найкраще пристосовані до південних територій Свропи, проте вони також продуктивні в Північній Європі, але можуть бути не такі холодостійкі, як сорти північного походження. Результати досліджень вирощування світчграсу у Свропі показують, що ці сорти можуть вирощуватися північніше у Свропі, порівняно 3 американським континентом, можливо із-за морського клімату. Сорт Кейв-інрок, адаптований до умов північно-західної Свропи (Великобританія, Нідерланди), в умовах України показує досить добру продуктивність i зимостійкість [21].

Отже, недостатність вивченість питання потребує проведення відповідних досліджень та встановлення особливостей формування насіннєвої продуктивності світчграсу.

Метою дослідження $\epsilon$ встановлення впливу умов вирощування на елементи продуктивності та урожайність насіння проса прутоподібного.

Завдання досліджень передбачали визначення особливостей формування кількісних показників рослин залежно від елементів технології вирощування, погодних умов та їхнього впливу на урожайність насіння світчграсу.

Методика проведення досліджень. Вивчення особливостей росту і розвитку рослин та насіннєвої продуктивності світчграсу залежно від агротехніки його вирощування проводили в умовах центрального Лісостепу України на маргінальних землях.

Експеримент здійснено згідно з методикою Б. О. Доспєхова [2] за схемою багатофакторного експерименту із рослинами світчграсу сорту Кейв-ін-рок.

Схема експерименту поєднувала: Фактор А - рік (2014-2016 рр.); Фактор Б - ширина міжряддя: 30 (ШM1), 45 (ШМ2), 60 (ШМ3), 75 см (ШМ3); фактор В - підживлення (варіант 1 - без підживлення, варіант 2 - весняне підживлення посівів).

Повторність досліду - чотириразова. Ділянки розміщені рендомізовано. Площа облікової ділянки становила $50 \mathrm{~m}^{2}$. 
Вирощування світчграсу здійснювали відповідно до науково-практичних рекомендацій $[5,9]$, біометричні вимірювання та визначення кількісних показників рослин проводили згідно з методикою [7]. Урожай насіння визначали ваговим методом шляхом зважування насіннєвого матеріалу з кожного варіанту досліду у чотирикратній повторності [12].

Статистичний аналіз експериментальних даних проводили шляхом дисперсійного аналізу 3 використанням програм Excel та Statistica 6.0.

Результати досліджень. Погодні умови під час вегетації проса прутоподібного різнилися як за середньодобовою температурою повітря, так i за середньомісячною кількістю опадів порівняно із середньо багаторічними даними (рис. 1-2).

За роки дослідження (2014-2016 рр.) середньодобова температура повітря мала відхилення від середньобагаторічних показників зі значним збільшенням протягом весняно-літньої вегетації світчграсу. Найбільш жаркими періодами літа виявилися липень і серпень. Кількість опадів протягом травня була досить нерівномірною окремі роки за цей період були посушливі
(2014 р.), 2015 та 2016 роки мали показники, близькі до середньобагаторічних, або значно перевищували їх. Літній період вегетації світчграсу характеризувався контрастними умовами зволоження: на початку літнього періоду 2014 рік був досить зволожений, з відсутністю опадів у 2015 і 2016 pр., на закінчення періоду відмічаємо подібну тенденцію. Протягом липня - серпня рослини світчграсу були достатньо забезпечені вологою в умовах 2016 року зі значним зменшенням кількості опадів, порівняно із середньобагаторічними в окремі періоди 2014-2015 років. Це дало можливість оцінити реакцію світчграсу на умови вирощування протягом трьохрічного циклу в площині формування кількісних показників рослин та насіннєвої продуктивності. Більш об'єктивний показник, що характеризує погодні умови дослідження, це гідротермічний коефіцієнт (ГТК). За роками дослідження гідротермічний коефіцієнт весняно-літньої вегетації світчграсу становив: 2014 рік - 1,34 (вологий), 2015 рік - 0,84 (сухий), 2016 рік - 1,20 (вологий).

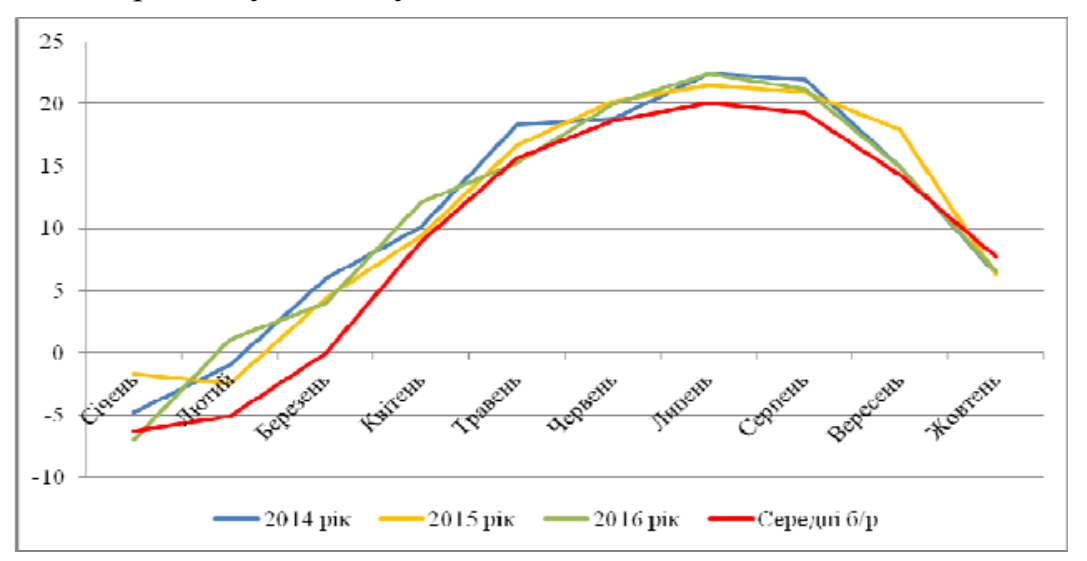

Рис. 1. Середньодбова температура повітря порівняно із середньобагаторічними даними протягом вететації світчграсу, 2014-2016 pр.

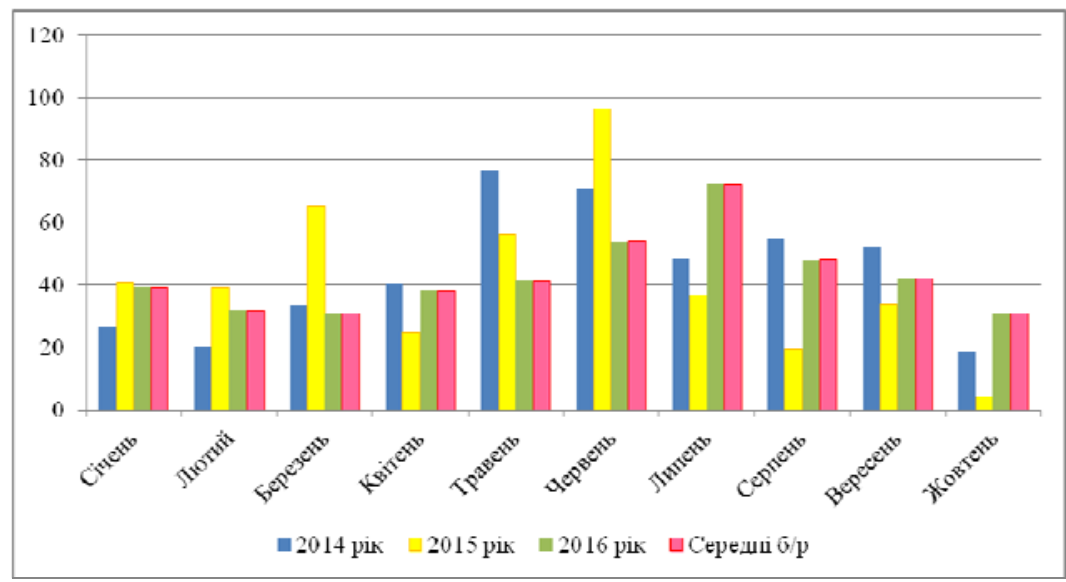

Рис. 2. Кількість опадів порівняно із середньобагаторічними даними протягом вететації cвimчграсу, 2014-2016 pp. 


\section{СІЛЬСЬКЕ ГОСПОДАРСТВО. РОСЛИННИЦТВО}

Кількісні показники рослин проса прутоподібного, залежно від погодних умов року та елементів технології вирощування, характеризувалися значним варіюванням (табл. 1, рис. 3).

В умовах 2014 року висота рослин варіювала від 140,1 до 149,8 см, у 2015 році - від 148,0 до 161,5 см, у 2016 році - від 152,0 до 180,0 см.

Незалежно від умов року дослідження, суттєво більшу висоту, порівняно із контрольними варіантами, рослини проса прутоподібного забезпечували на варіантах із підживленням та збільшенням ширини міжряддя (рис. 3). За роки дослідження чітко простежується кореляційна залежність: зі збільшенням ширини міжряддя (від 30 до 75 см) на фоні застосування весняного підживлення зростає висота рослин проса прутоподібного. Це свідчить про те, що за збільшеної площі рослин буде зростати висота стеблостою культури, і навпаки (рис. 4).
Густота стеблостою проса прутоподібного за роки проведення експерименту мала чітку тенденцію до зростання - від 124,0 у 2014 році до 313,0 шт./м.П. у 2016 році (табл. 2).

В умовах 2014 року кількість стебел проса прутоподібного змінювалась у межах - від 124,0 до 156,0 шт./м.П., у 2015 році - від 146,0 до 213,0 см, у 2016 році - від 215,0 до 313,0 см.

За густотою стеблостою виокремилися варіанти 3 шириною міжряддя 45 см, на яких проводили весняне підживлення рослин проса прутоподібного. Це пов'язано як з елементами технології вирощування (ширина міжряддя, застосування підживлення посівів), так і $з$ погодними умовами вегетаційного періоду та видовими особливостями культури за багаторічного циклу вирощування (збільшення кореневої системи, відростання нових пагонів із сплячих бруньок та ін.).

\section{1. Висота рослин проса прутоподібного третього-п'ятого років вететації, 2014-2016 рр.}

\begin{tabular}{|c|c|c|c|}
\hline Рік (фактор А) & $\begin{array}{c}\text { Ширина міжряддя } \\
\text { (фактор Б) }\end{array}$ & $\begin{array}{c}\text { Підживлення } \\
\text { (фактор В) }\end{array}$ & Висота рослин, см \\
\hline \multirow{8}{*}{2014} & \multirow{2}{*}{$30 \mathrm{~cm}$} & варіант 1 & 140,1 \\
\hline & & варіант 2 & 145,7 \\
\hline & \multirow{2}{*}{$45 \mathrm{~cm}$} & варіант 1 & 130,2 \\
\hline & & варіант 2 & 136,7 \\
\hline & \multirow{2}{*}{$60 \mathrm{~cm}$} & варіант 1 & 131,4 \\
\hline & & варіант 2 & 137,1 \\
\hline & \multirow{2}{*}{$75 \mathrm{~cm}$} & варіант 1 & 145,6 \\
\hline & & варіант 2 & 149,8 \\
\hline \multirow{8}{*}{2015} & \multirow{2}{*}{$30 \mathrm{~cm}$} & варіант 1 & 148,0 \\
\hline & & варіант 2 & 149,5 \\
\hline & \multirow{2}{*}{$45 \mathrm{~cm}$} & варіант 1 & 140,4 \\
\hline & & варіант 2 & 145,6 \\
\hline & \multirow{2}{*}{$60 \mathrm{~cm}$} & варіант 1 & 141,3 \\
\hline & & варіант 2 & 147,2 \\
\hline & \multirow{2}{*}{$75 \mathrm{~cm}$} & варіант 1 & 156,7 \\
\hline & & варіант 2 & 161,5 \\
\hline \multirow{8}{*}{2016} & \multirow{2}{*}{$30 \mathrm{~cm}$} & варіант 1 & 156,8 \\
\hline & & варіант 2 & 164,3 \\
\hline & \multirow{2}{*}{$45 \mathrm{~cm}$} & варіант 1 & 152,0 \\
\hline & & варіант 2 & 155,3 \\
\hline & \multirow{2}{*}{$60 \mathrm{~cm}$} & варіант 1 & 161,4 \\
\hline & & варіант 2 & 170,5 \\
\hline & \multirow{2}{*}{$75 \mathrm{~cm}$} & варіант 1 & 176,4 \\
\hline & & варіант 2 & 180,0 \\
\hline & & $\mathrm{HIP}_{05}$ (фактор А) & 4,23 \\
\hline & & $\mathrm{HIP}_{05}$ (фактор В) & 7,11 \\
\hline & & $\mathrm{HIP}_{05}$ (фактор C) & 5,23 \\
\hline & & $\mathrm{HIP}_{05}$ (фактор АBC) & 3,80 \\
\hline
\end{tabular}

Примітка: варіант 1 - варіант без підживлення, варіант 2 - варіант 3 підживленням. 


\section{СІЛЬСЬКЕ ГОСПОДАРСТВО. РОСЛИННИЦТВО}

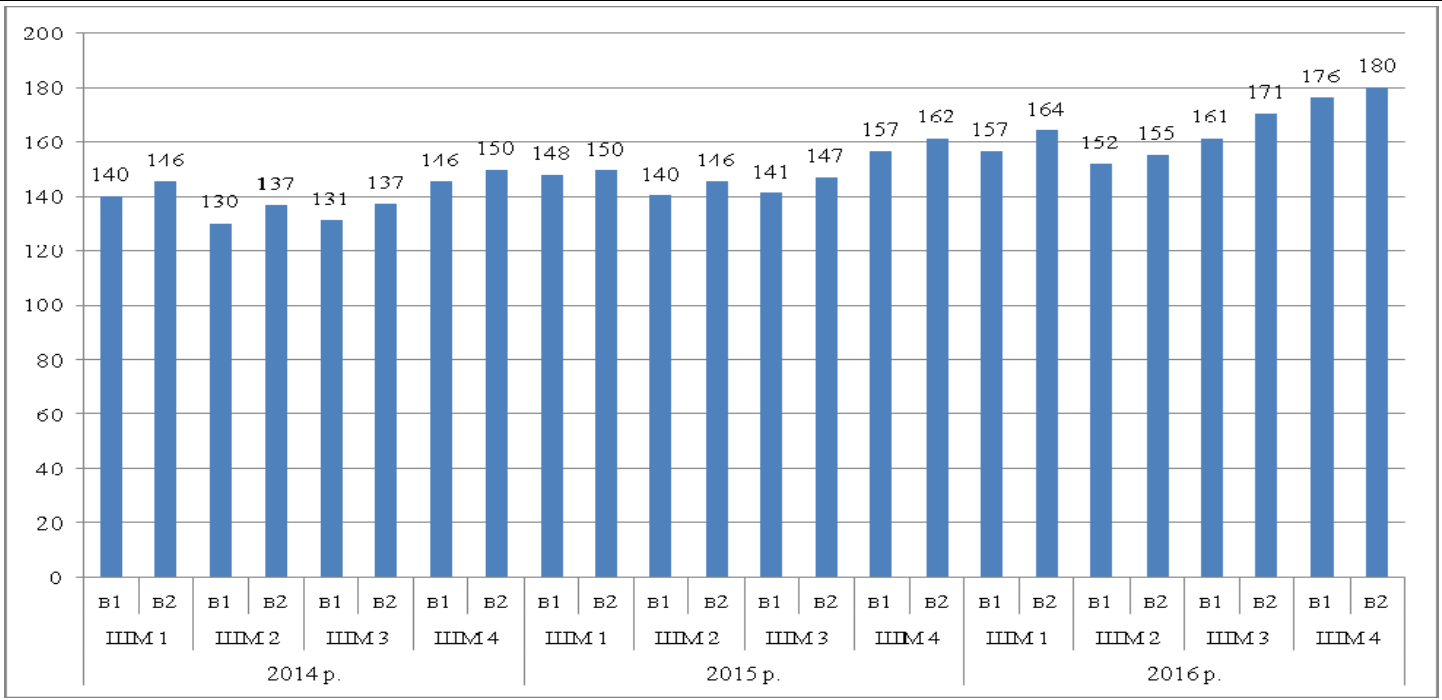

Рис. 3. Висота рослин проса прутоподібного залежнно від елементів технології вирощування, 2014-2016 pp.

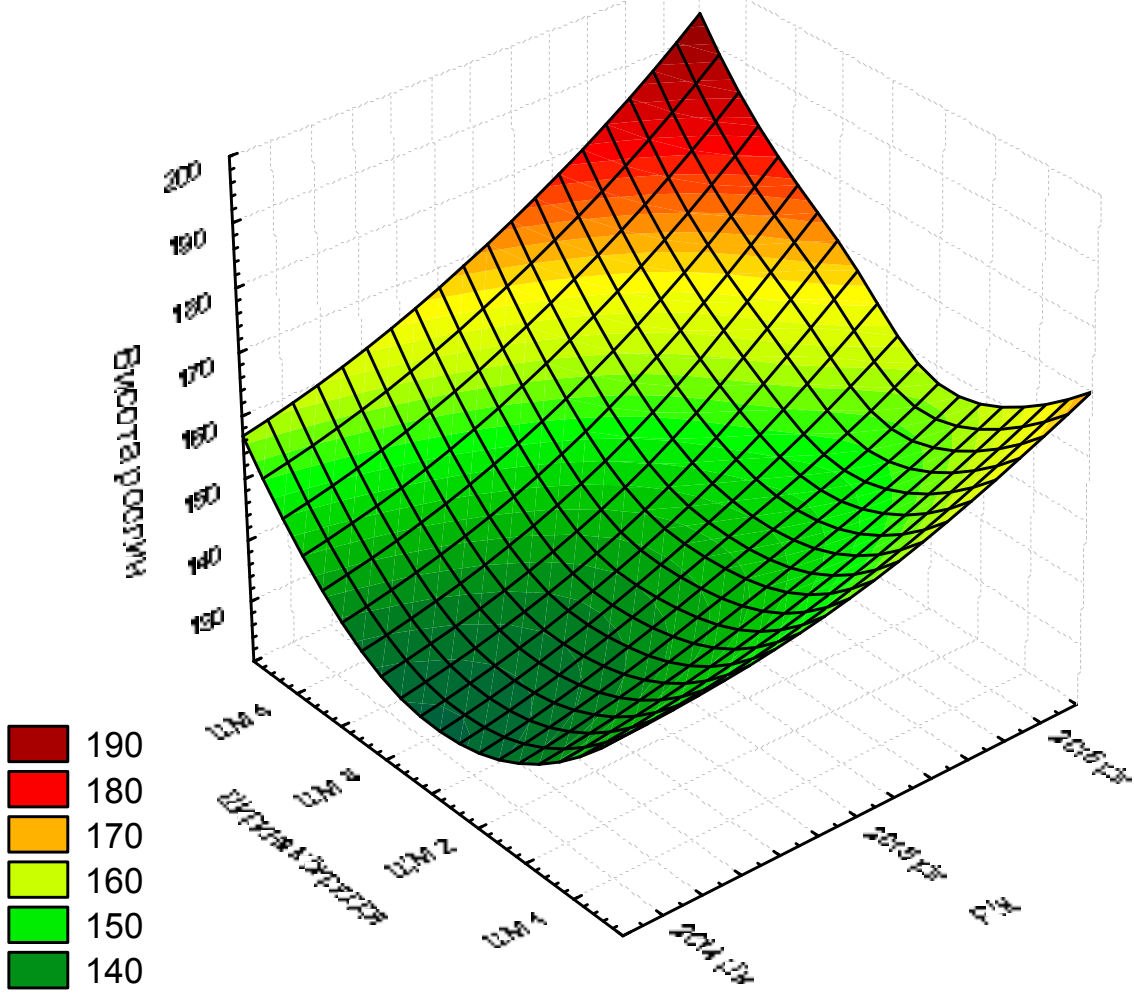

A 


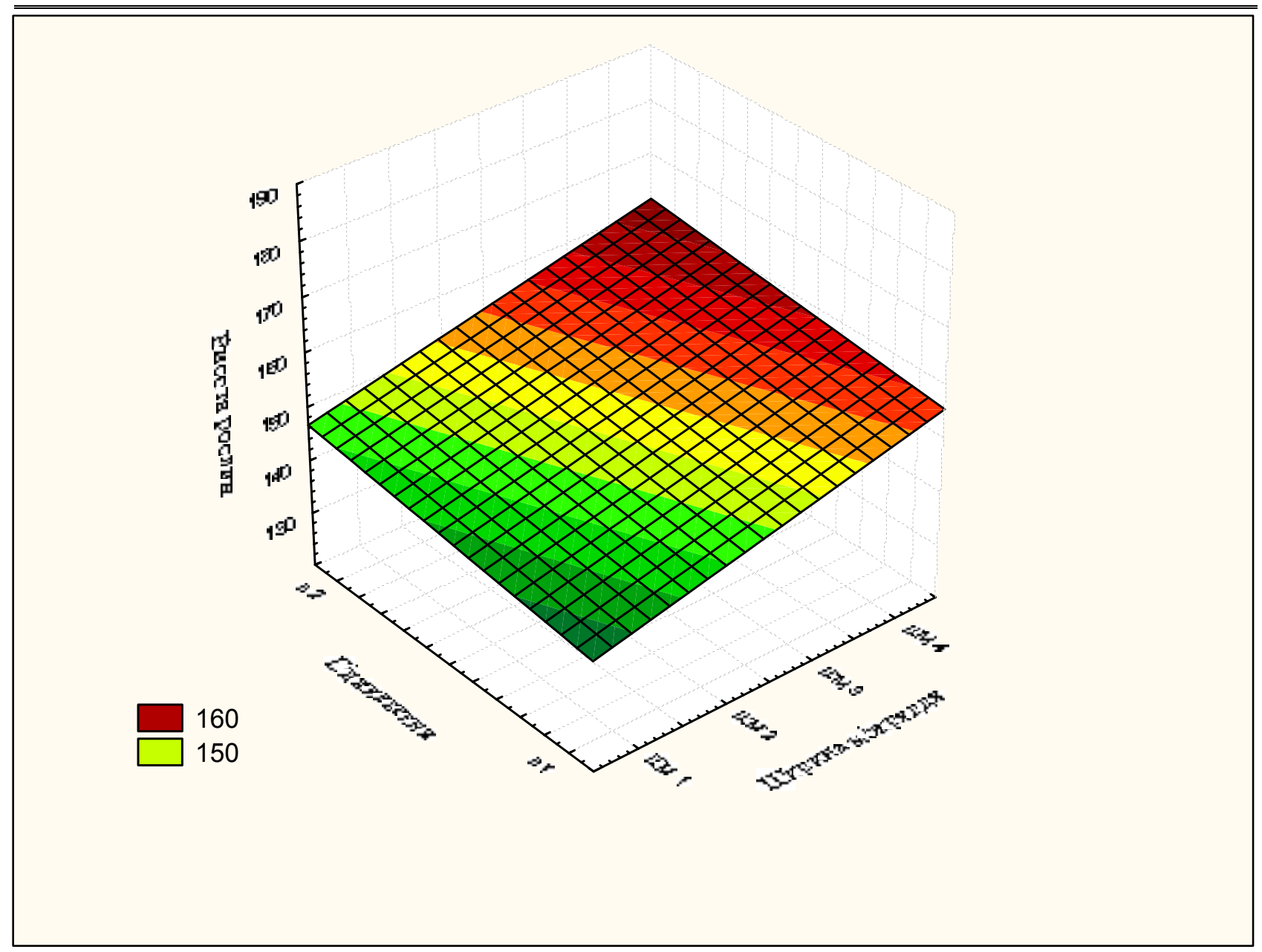

Б

Рис. 4. Множинна залежність між иириною міжряддя і роком дослідження (А), застосування підживлення рослин (Б) та вистою стеблостою проса прутоподібного, 2014-2016 рр.

Динаміку кількості стебел у рослин проса прутоподібного залежно від елементів технології вирощування за 2014-2016 роки наведено на рис. 5.

За роки дослідження найбільшу кількість стебел просо прутоподібне забезпечило в разі вирощування рослин на міжрядді 45 см та проведення весняного підживлення посівів: у 2014 році на рівні 156,0 шт./м.П., у 2015 році - 213,0 шт./м.П., у 2016 році - 313,0 шт./м.п.

Залежність між шириною міжряддя і роком дослідження, застосування підживлення рослин та густотою стеблостою проса прутоподібного за 2014-2016 рр. наведено на рис. 6.

За встановлення зв'язку між висотою рослин та кількістю стебел проса прутоподібного визначено, що ці показники взаємозалежні $(\mathrm{r}=0,74)$, тобто із збільшенням висоти рослин буде збільшуватись кількість стебел, та навпаки $(\mathrm{d}=0,55)$, (рис. 7).
Порівнюючи отримані результати за роки проведення дослідження, можна стверджувати, що вищими рослини проса прутоподібного були на варіантах із проведенням підживлення та за ширини міжряддя 60-75 см. Кількість стебел проса прутоподібного була більшою за вирощування його 3 шириною міжряддя 45 см та проведення весняного підживлення рослин.

Урожайність насіння проса прутоподібного (табл. 3) залежить як від елементів технології вирощування (рис. 8), так і від кількісних показників рослин - висоти та густоти стеблостою (рис. 9-10).

3-поміж варіантів, поставлених на вивчення, найбільший вплив на урожайність насіння проса прутоподібного має застосуванню міжряддя $60 \mathrm{~cm}$. Як збільшення, так і зменшення ширини міжряддя призводить до зниження насіннєвого врожаю культури (рис. 6). 
СІЛЬСЬКЕ ГОСПОДАРСТВО. РОСЛИННИЦТВО

\section{2. Кількість стебел на 1 м.п. проса прутоподібного третього-п'ятого років вететацї̈,} 2014-2016 pp.

\begin{tabular}{|c|c|c|c|}
\hline Рік (фактор А) & $\begin{array}{c}\text { Ширина міжряддя } \\
\text { (фактор Б) }\end{array}$ & $\begin{array}{c}\text { Підживлення } \\
\text { (фактор В) }\end{array}$ & $\begin{array}{c}\text { Кількість стебел, } \\
\text { шт./м.п. }\end{array}$ \\
\hline \multirow{8}{*}{2014} & \multirow{2}{*}{$30 \mathrm{~cm}$} & варіант 1 & 124,0 \\
\hline & & варіант 2 & 130,0 \\
\hline & \multirow{2}{*}{$45 \mathrm{~cm}$} & варіант 1 & 146,0 \\
\hline & & варіант 2 & 156,0 \\
\hline & \multirow{2}{*}{$60 \mathrm{~cm}$} & варіант 1 & 134,0 \\
\hline & & варіант 2 & 140,0 \\
\hline & \multirow{2}{*}{$75 \mathrm{~cm}$} & варіант 1 & 130,0 \\
\hline & & варіант 2 & 129,0 \\
\hline \multirow{8}{*}{2015} & \multirow{2}{*}{$30 \mathrm{~cm}$} & варіант 1 & 146,0 \\
\hline & & варіант 2 & 166,0 \\
\hline & \multirow{2}{*}{$45 \mathrm{~cm}$} & варіант 1 & 201,0 \\
\hline & & варіант 2 & 213,0 \\
\hline & \multirow{2}{*}{$60 \mathrm{~cm}$} & варіант 1 & 154,0 \\
\hline & & варіант 2 & 163,0 \\
\hline & \multirow{2}{*}{$75 \mathrm{~cm}$} & варіант 1 & 190,0 \\
\hline & & варіант 2 & 205,0 \\
\hline \multirow{8}{*}{2016} & \multirow{2}{*}{$30 \mathrm{~cm}$} & варіант 1 & 215,0 \\
\hline & & варіант 2 & 226,0 \\
\hline & \multirow{2}{*}{$45 \mathrm{~cm}$} & варіант 1 & 289,0 \\
\hline & & варіант 2 & 313,0 \\
\hline & \multirow{2}{*}{$60 \mathrm{~cm}$} & варіант 1 & 278,0 \\
\hline & & варіант 2 & 289,0 \\
\hline & \multirow{2}{*}{$75 \mathrm{~cm}$} & варіант 1 & 271,0 \\
\hline & & варіант 2 & 285,0 \\
\hline & & $\mathrm{HIP}_{05}$ (фактор A) & 12,53 \\
\hline & & $\mathrm{HIP}_{05}$ (фактор В) & 36,89 \\
\hline & & $\mathrm{HIP}_{05}$ (фактор C) & 24,81 \\
\hline & & $\mathrm{HIP}_{05}$ (фактор ABC) & 6,62 \\
\hline
\end{tabular}

Примітка: варіант 1 - варіант без підживлення, варіант 2 - варіант 3 підживленням

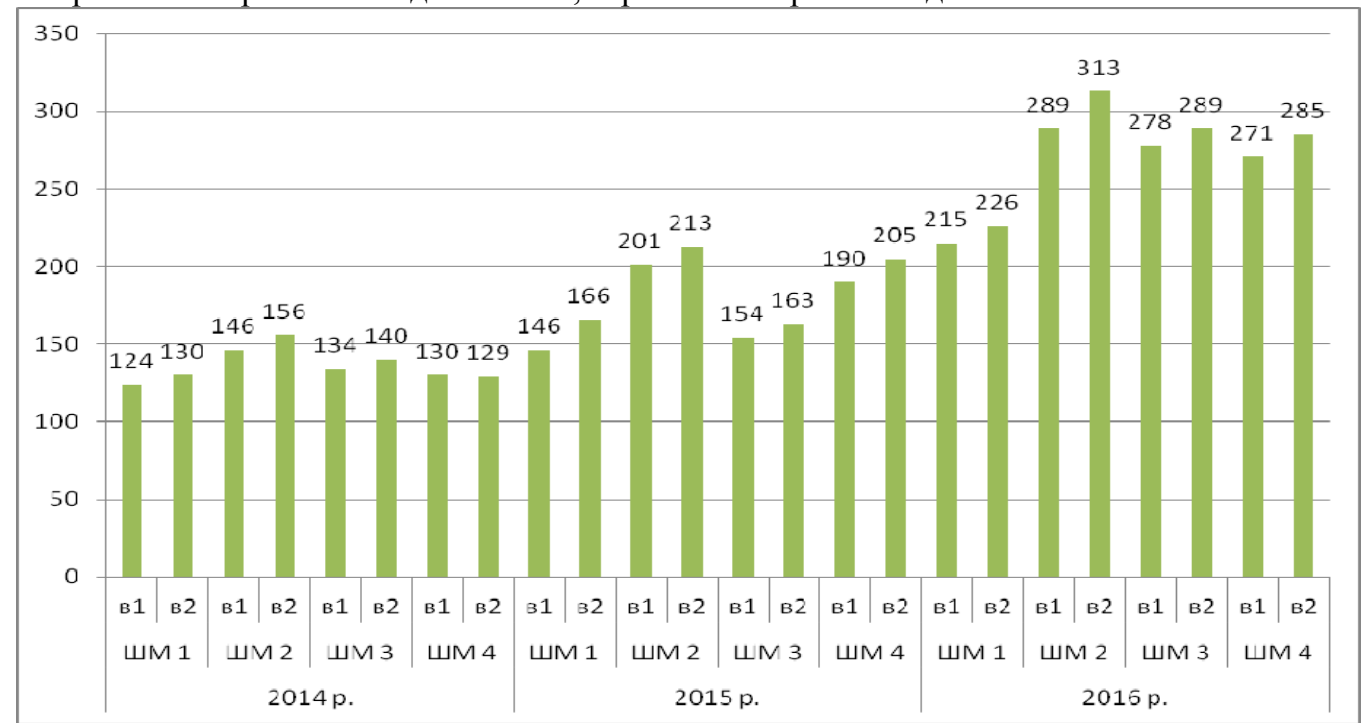

Рис. 5. Кількість стебел рослин проса прутоподібного залежно від елементів технології вирощування, 2014-2016 рр. 




A

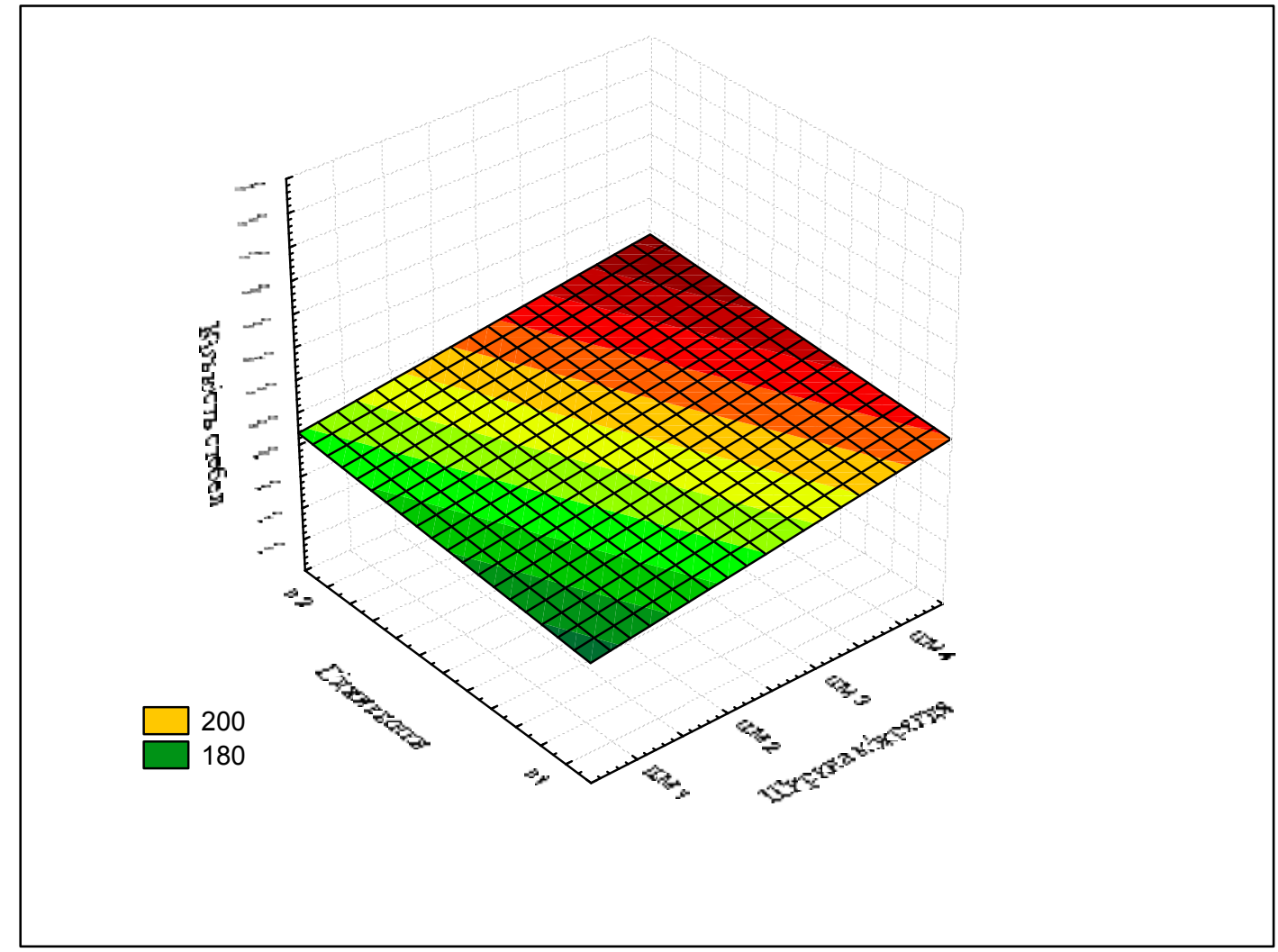

Б

Рис. 6. Множинна залежність між иириною міжряддя і роком дослідження (А), застосування підживлення рослин (Б) та густотою стеблостою проса прутоподібного, 2014-2016 рр. 


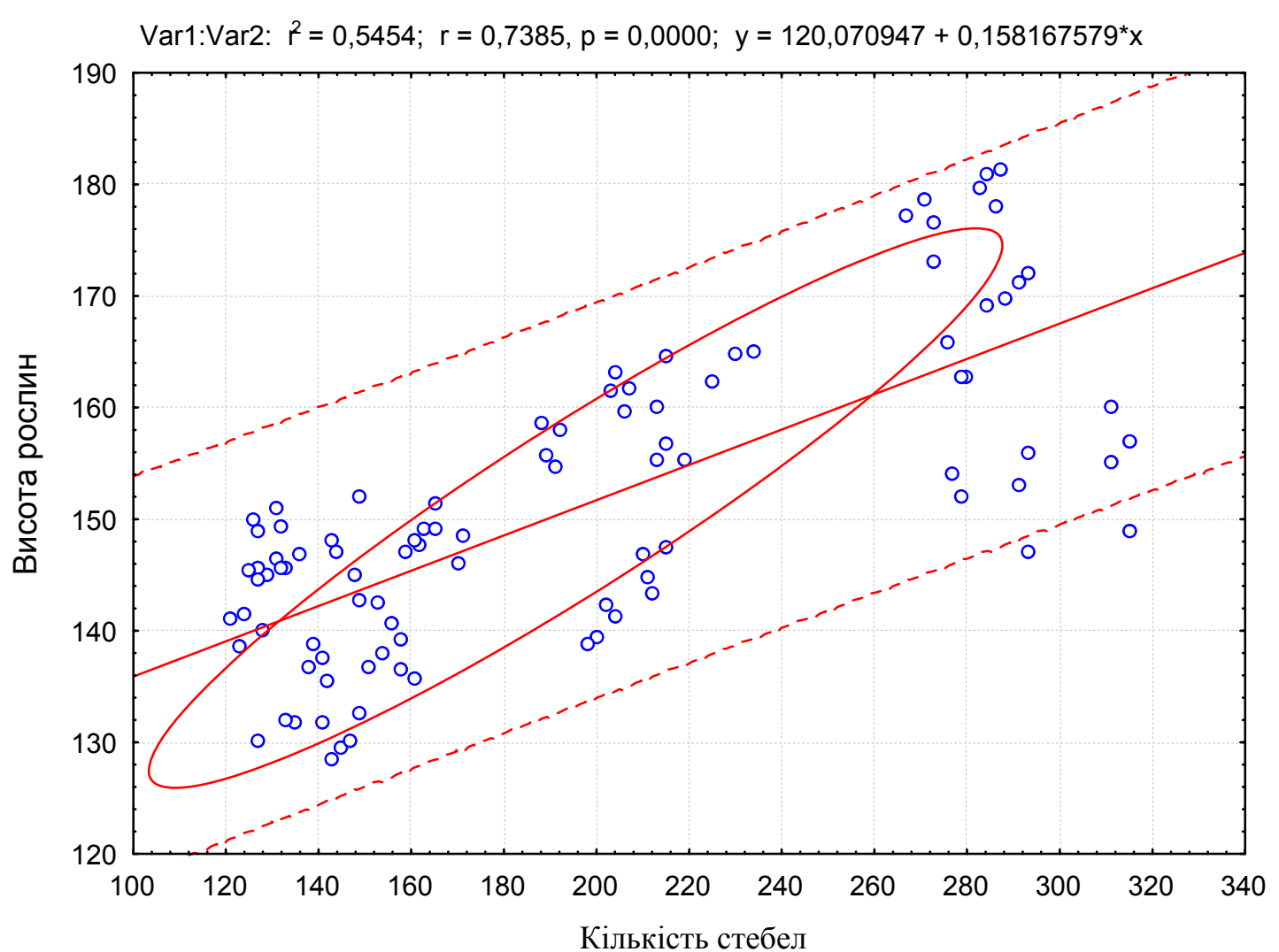

Рис. 7. Кореляційна залежність між висотою рослин та кількістю стебел проса прутоподібного, 2014-2016 pp.

Поряд із цим визначено, що кількісні показники рослин (висота і густота стеблостою) мають середній кореляційний зв'язок 3 урожайністю насіння проса прутоподібного (рис. 9-10).

За результатами кореляційно-регресійного аналізу визначено, що урожайність насіння проса прутоподібного на $26 \%$ залежить від висоти рослин за коефіцієнта кореляції $\mathrm{r}=0,51$, та на $23 \%$ - від кількості стебел за коефіцієнта кореляції $\mathrm{r}=0,48$.

За встановлення зв'язку між погодними умовами вирощування (середньодобова температура повітря та кількість опадів) та урожайністю насіння проса прутоподібного встановлено множинну залежність (рис. 11), згідно з якою визначено, що найбільший вплив на формування насіннєвої продуктивності культури за роки дослідження має середньомісячна кількість опадів 2080 мм та середньодобова температура повітря більше $22{ }^{\circ} \mathrm{C}$.

Висновки:

1. Порівняно із контрольними варіантами, рослини проса прутоподібного істотно більшу ви- соту стеблостою забезпечували на варіантах із підживленням та збільшенні ширини міжряддя. Варіанти 3 шириною міжряддя $45 \mathrm{~cm}$, на яких проводили весняне підживлення рослин, забезпечили найбільшу густоту стеблостою проса прутоподібного - від 156,0 до 313,0 шт./м.п.

2. Встановлено, що найбільший вплив на урожайність насіння проса прутоподібного має застосування підживлення за вирощування рослин 3 шириною міжряддя $60 \mathrm{~cm}-$ від 0,57 до 0,72 т/га. Як збільшення, так і зменшення ширини міжряддя призводить до зниження насіннєвого врожаю культури. Урожайність насіння проса прутоподібного на $26 \%$ залежить від висоти рослин за коефіцієнта кореляції $\mathrm{r}=0,51$, та на $23 \%$ - від кількості стебел за коефіцієнта кореляції $\mathrm{r}=0,48$.

3. Для умов років дослідження встановлено закономірність - зі збільшенням середньодобової температури повітря понад $22{ }^{\circ} \mathrm{C}$ та середньомісячної кількості опадів більше 20 мм за весняно-літню вегетацію культури буде зростати урожайність насіння проса прутоподібного. 
СІЛЬСЬКЕ ГОСПОДАРСТВО. РОСЛИННИЦТВО

3. Урожайність (m/za) проса прутоподібного третього-п'ятого років вететації, 2014-2016 рр.

\begin{tabular}{|c|c|c|c|}
\hline Рік (фактор А) & $\begin{array}{c}\text { Ширина міжряддя } \\
\text { (фактор Б) }\end{array}$ & $\begin{array}{c}\text { Підживлення } \\
\text { (фактор В) }\end{array}$ & Урожайність, т/га \\
\hline \multirow{8}{*}{2014} & \multirow{2}{*}{$30 \mathrm{~cm}$} & варіант 1 & 0,36 \\
\hline & & варіант 2 & 0,41 \\
\hline & \multirow{2}{*}{$45 \mathrm{~cm}$} & варіант 1 & 0,38 \\
\hline & & варіант 2 & 0,44 \\
\hline & \multirow{2}{*}{$60 \mathrm{~cm}$} & варіант 1 & 0,50 \\
\hline & & варіант 2 & 0,57 \\
\hline & \multirow{2}{*}{$75 \mathrm{~cm}$} & варіант 1 & 0,47 \\
\hline & & варіант 2 & 0,51 \\
\hline \multirow{8}{*}{2015} & \multirow{2}{*}{$30 \mathrm{~cm}$} & варіант 1 & 0,39 \\
\hline & & варіант 2 & 0,44 \\
\hline & \multirow{2}{*}{$45 \mathrm{~cm}$} & варіант 1 & 0,41 \\
\hline & & варіант 2 & 0,47 \\
\hline & \multirow{2}{*}{$60 \mathrm{~cm}$} & варіант 1 & 0,55 \\
\hline & & варіант 2 & 0,61 \\
\hline & \multirow{2}{*}{$75 \mathrm{~cm}$} & варіант 1 & 0,51 \\
\hline & & варіант 2 & 0,54 \\
\hline \multirow{8}{*}{2016} & \multirow{2}{*}{$30 \mathrm{~cm}$} & варіант 1 & 0,43 \\
\hline & & варіант 2 & 0,49 \\
\hline & \multirow{2}{*}{$45 \mathrm{~cm}$} & варіант 1 & 0,47 \\
\hline & & варіант 2 & 0,52 \\
\hline & \multirow{2}{*}{$60 \mathrm{~cm}$} & варіант 1 & 0,67 \\
\hline & & варіант 2 & 0,72 \\
\hline & \multirow{2}{*}{$75 \mathrm{~cm}$} & варіант 1 & 0,59 \\
\hline & & варіант 2 & 0,65 \\
\hline \multicolumn{3}{|c|}{$\mathrm{HIP}_{05}$ (фактор А) } & 0,05 \\
\hline & & $\mathrm{HIP}_{05}$ (фактор В) & 0,045 \\
\hline & & $\mathrm{HIP}_{05}$ (фактор C) & 0,04 \\
\hline & & $\mathrm{HIP}_{05}$ (фактор ABC) & 0,11 \\
\hline
\end{tabular}

Примітка: варіант 1 - варіант без підживлення, варіант 2 - варіант 3 підживленням 

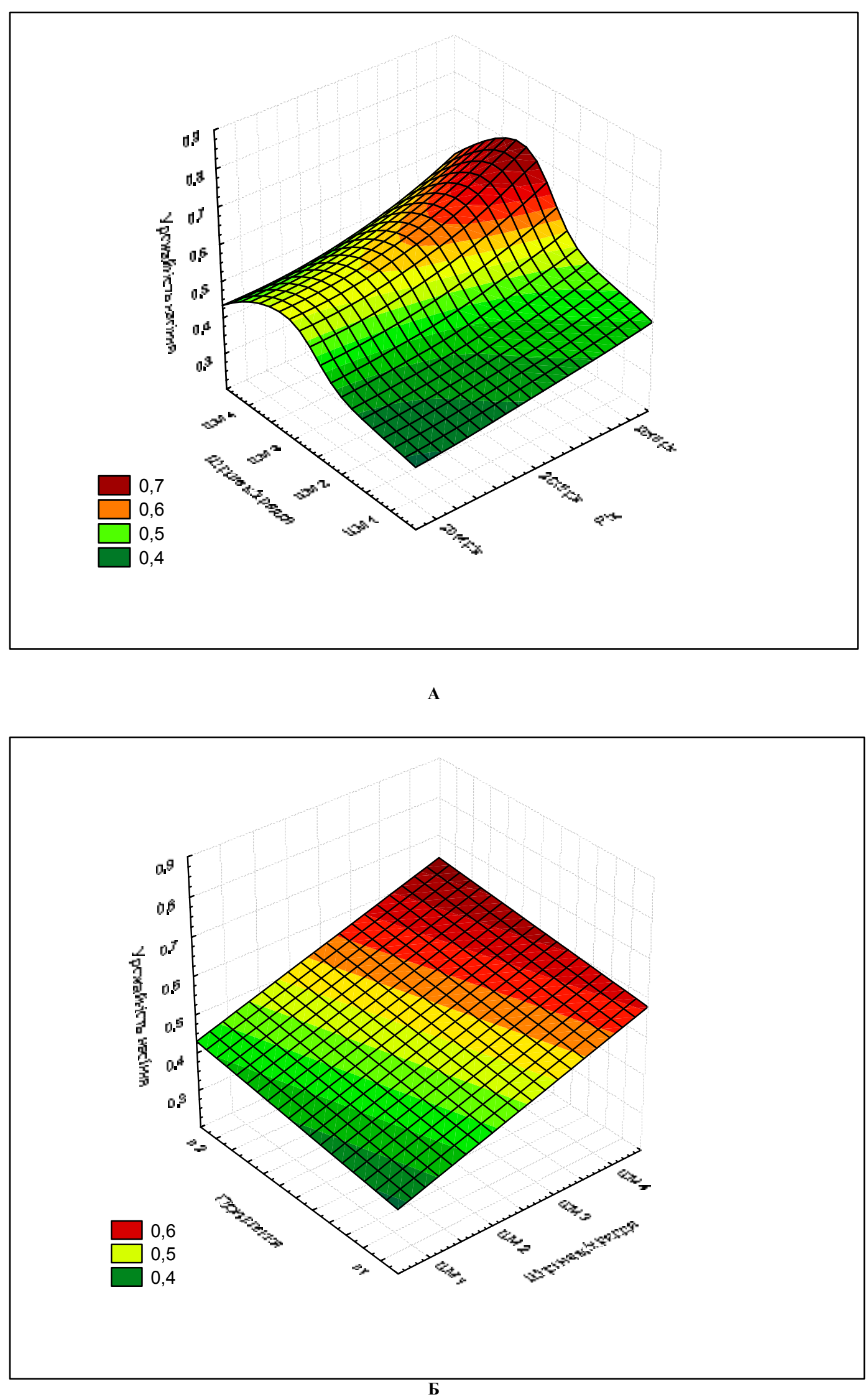

Рис. 8. Множинна залежність між иириною міжряддя і роком дослідження (А), застосування підживлення рослин (Б) та урожайністю насіння проса прутоподібного, 2014-2016 рр. 


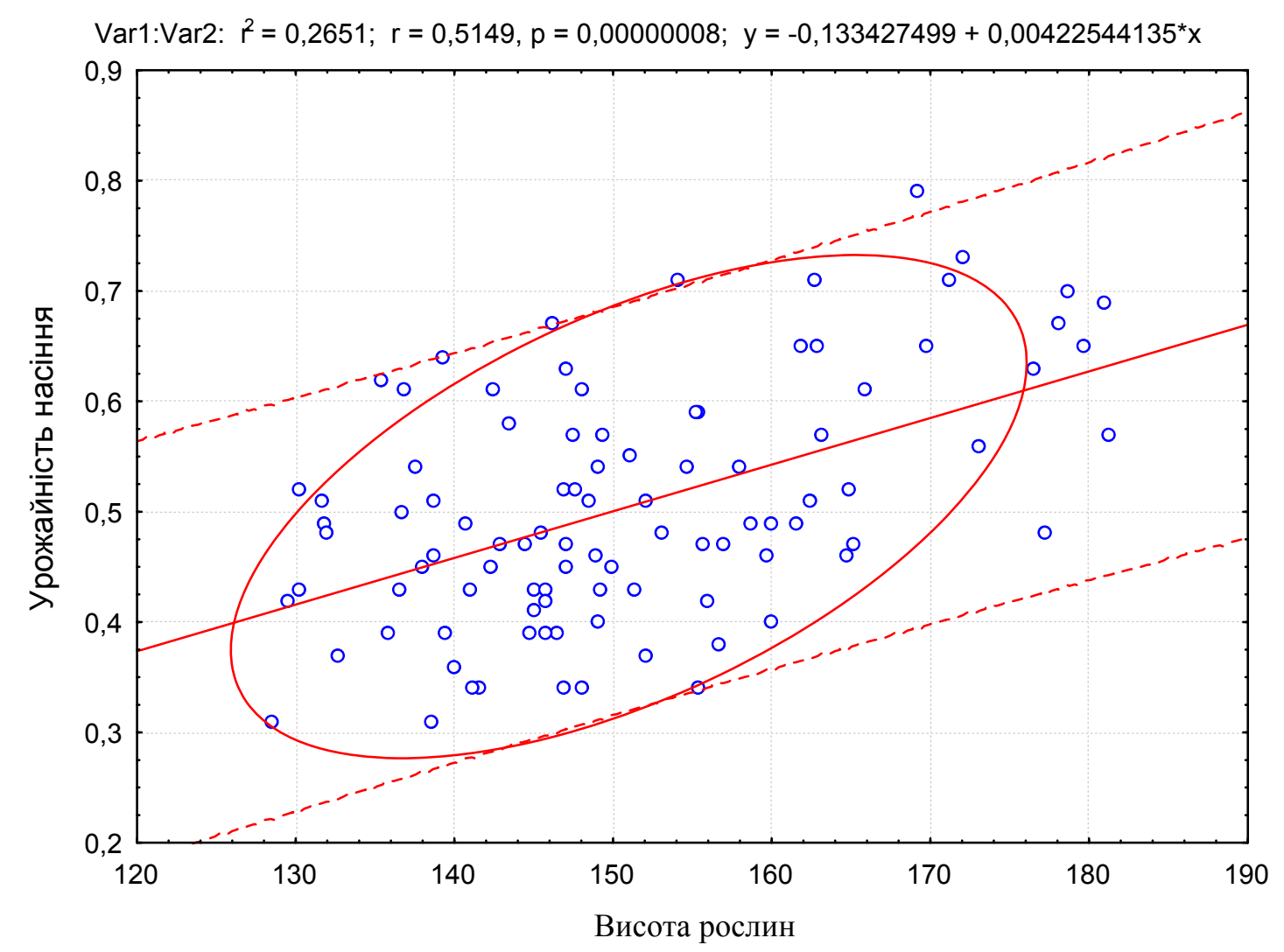

Рис. 9. Кореляційна залежність між висотою рослин та урожайністю насіння проса прутоподібного, 2014-2016 pp.



Рис. 10. Кореляційна залежність між кількістю стебел та урожайністю насіння проса прутоподібного, 2014-2016 pp. 


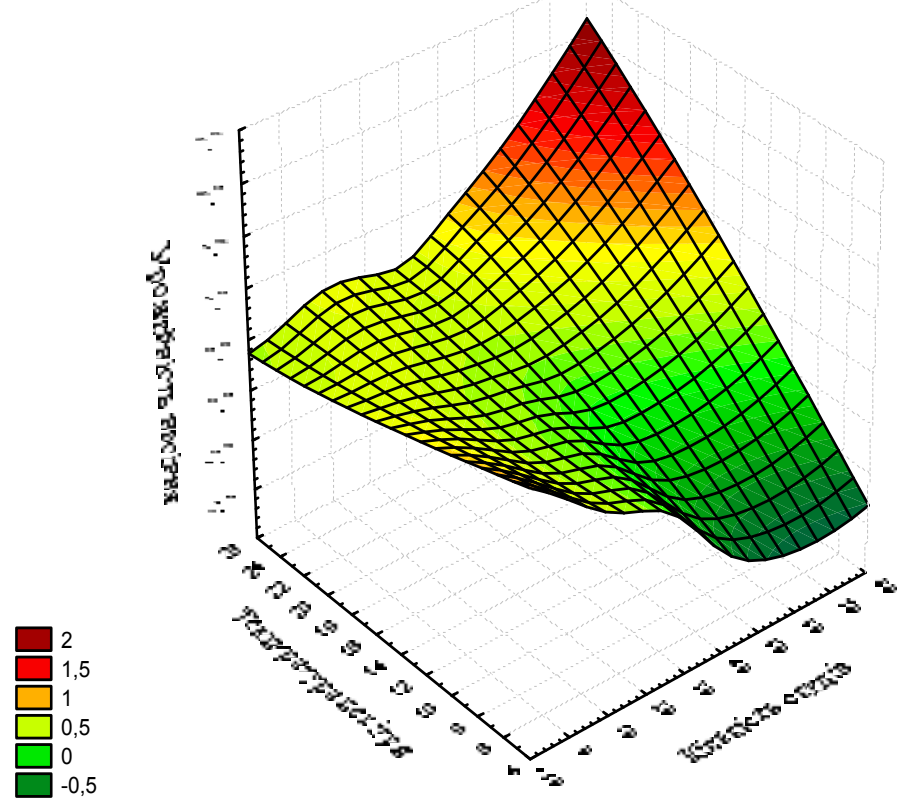

A

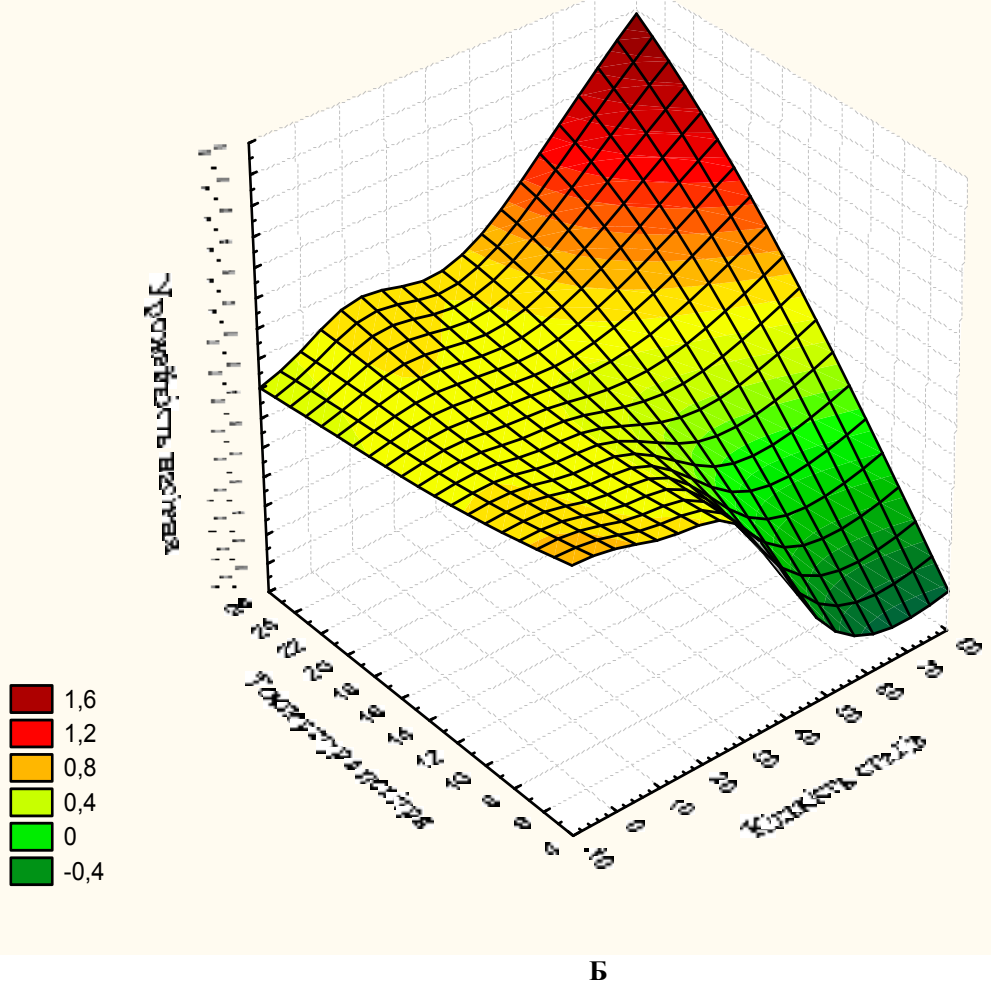

Рис. 11. Множинна залежність між середньодобовою температурою повітря та кількістю опадів і урожайністю насіння проса прутоподібного, 2014-2016 р.

Примітка: А - варіанти без підживлення, Б - варіанти із підживленням посівів. 


\section{БІБЛІОГРАФІЯ}

1. Биологические особенности и потенциал урожайности фитомассы проса прутьевидного / Ю. Е. Домашенко, М. И. Кулик, М. В. Ларионов / Актуальные задачи биологии и экологии в региональном контексте : монография ; под ед. М. В. Ларионова. - Новосибирск: Изд. АНС СибАК, 2016. - С. 38-64. p

2. Доспехов Б. А. Методика полевого опыта (с основами статистической обработки результатов исследований) / Б. А. Доспехов. - Изд. 5-е, перераб. и доп. - М. : Агропромиздат, 1985. - 351 с.

3. Кулик М. И. Адаптивный потенциал проса прутьевидного в условиях Украины / М. И. Кулик // Вестник Курганской ГСХА, 2015. - Вып. №1(13). - С. 28-30.

4. Кулик М. І. Биологические особенности и потенциал урожайности проса прутьевидного Panicum virgatum L. / Актуальные задачи биологии и экологии в региональном контексте: коллективная монография; под ред. М.В. Ларионова. - Новосибирск: Изд. НАС СибАК, 2016. C. 38-64.

5. Кулик M. I. Використання деградованих земель для вирощування енергетичних культур i виробництва біопалива: науково-практичні рекомендації. - Полтава, 2015. - 72 с.

6. Кулик M. I. Вплив елементів технології вирощування на урожайність сортів проса прутоподібного / Екологічні, соціальні й економічні аспекти розвитку АПК на засадах раціонального природокористування: колективна монографія ; за ред. П. В. Писаренка, Т. О. Чайки, О. О. Ласло. - Полтава: Видавництво «Сімон», 2015. C. 194-205.

7. Кулик M. I. Методика проведення польових та лабораторних досліджень 3 просом прутоподібним (Panicum virgatum L.) / М. І. Кулик, Д. Б. Рахметов, В. Л. Курило. - Полтава: РВВ ПДАА, 2017. $-24 \mathrm{c}$.

8. Кулик M. I. Насіннєва продуктивність проса лозовидного (Panicum virgatum L.) / М. І. Кулик // Селекція, генетика та насінництво сільськогосподарських культур: тези Міжнародної науково-практичної конференції, присвяченої 50річчю селекції рослин в ПДАА. - Полтава, ПДАА, 22-23 травня 2013 р. - С. 26-28.

9. Методичні рекомендації з проведення основного та передпосівного обробітку грунту і сівби проса лозовидного / [В. Л. Курило, М. Я. Гументик, Г. С. Гончарук, та ін.]. - К. : Інститут біоенергетичних культур i цукрових буряків HAAH, 2012. - $26 \mathrm{c}$.

10. Рахметов Д. Б. Panicum virgatum L. - пер- спективний інтродуцент у Національному ботанічному саду ім. М. М. Гришка НААНУ / Д. Б. Рахметов, О. М. Вергун, С. О. Рахметова // Інтродукція рослин. - Вип. 3(63), 2014. - С. 4-12.

11. Kulik M. Impact of seeding terms and row spacing on yield of switchgrass phytomass, biofuel and energy output (2016) Annals of Agrarian Science. - Volume 14, Issue 4. 331-334.

12. Kulyk M. Methods of calculation productivity phytomass for switchgrass in Ukraine / M. Kulyk, W. Elbersen. - Poltava, 2012. - 10 p.

13. Moser L. E. and Vogel K. P. Switchgrass, Big Bluestem, and Indiangrass. In: An introduction to grassland agriculture. R. F. Barnes, D. A. Miller and C. J. Nelson (eds.). Forages, 5th ed. Vol.1, Ames, IA: Iowa University Press, 1995. - P. 409-420.

14. Samson R. A. and Omielan J. A. Switchgrass: A potential biomass energy crop for ethanol production Thirteenth North American Prairie Conference. Windsor, Ontario. 1992. - P. 253-258.

15. Samuel B. McLaughlin, Lynn Adams Kszos. Development of switchgrass (Panicum virgatum) as a bioenergy feedstockin the United States. Biomass and Bioenergy 28 (2005) 515-535. https://eurekamag.com/pdf/004/004104150.pdf

16. Sanderson M. A., Reed R. L., McLaughlin S. B., Wullschleger S. D. at all. Switchgrass as a sustainable bioenergy crop. Bioresource Technology, 1996. - №56. - P. 83-93.

17. Stritzler N. P., Pagella J. H., Jouve V. V. and Ferri C. M.. Semi-arid warm-season grass yield and nutritive value in Argentina / J. Range Manage, 1996. - № 49 - P. 121-125.

18. Ocumpaugh W. R., Sanderson M. A., Hussey M. A., Read J. C., Tischler C. R. and Reed R. L.. Evaluation of switchgrass cultivars and cultural methods for biomass production in the southcentral U.S. Final report. Oak Ridge National Laboratory, Oak Ridge, TN,1997. contract \#19X-SL128C.

19. Turhollow A. F. Screening herbaceous lignocellulosic energy crops in temperate regions of the USA / Bioresource Technology, 1991. 36 - P. 247252.

20. Vogel K. P. Switchgrass. In: L. E. Moser et al., eds. Warm-season (C4) Grasses / ASA-CSSASSSA, Madison, WI, 2004. - P. 561-588.

21. Wolter Elbersen and Maksym Kulyk. Switchgrass Ukraine. Overview of switchgrass research and guidelines / Wageningen UR Food \& Biobased Research, 2013. -26 p.

http://edepot.wur.n1/282355

22. Wolf D. D. and Fiske D. A. (2009). Planting and managing switchgrass for forage, wildlife, and 


\section{СІЛЬСЬКЕ ГОСПОДАРСТВО. РОСЛИННИЦТВО}

conservation / Virginia Cooperative Extension, publication 418-013. Available from: http://pubs.ext.vt.edu/418/418-013/418-013_pdf.pdf

23. Wulschleger S. D. and Gunter L. E. Genetic

\section{ANNOTATION}

Kulyk M. I., Rozhko I. I. Regularities of yield formation of switchgrass seeds in the conditions of Forest-Steppe of Ukraine.

The article focuses attention on the necessity of studying the peculiarities of the formation of switchgrass yield for providing productive areas with sufficient amount of seed material. An attempt to determine the dependence of yield on the elements of cultivation technology in connection with the weather conditions of the growing season has been made. The experiment on studying seed efficiency of switchgrass was carried out under the conditions of the Forest-Steppe using methodological recommendations of domestic and foreign authors. The yield of seed was determined by weighing method by weighing the seed material from each variant of the field experiment.

In our study we used both general scientific methods (dialectics, experiment, analysis and synthesis) and special ones, among them: laboratory - the determination of quantitative indices of plants (height and density of stems); field - determination of the interaction of the subject with the object of research; calculation-weight - establishment of seed productivity and yield of seeds; mathematical analysis of interconnections and graphical representation of data in the experiment. diversity and long-term sustainability of yield in the bioenergy crop switchgrass / Environmental Sciences Division, Oak Ridge National Laboratory. Oak Ridge, TN. 1997.

Complex influence of the cultivation technology elements during the contrast conditions of crop vegetation upon the switchgrass yield has been established. It has been determined that the weather conditions (average daily air temperature and rainfall) during the growing season influenced on switchgrass yield. The highest seed yield is formed by growing plants at a width of rotation of $60 \mathrm{~cm}$, both wider and narrowed row spacings reduce this figure. The equivalent effect of biometric indices of plants (height and number of stems) on the yield of the seed of the switchgrass is determined. At the same time the application of spring crop yields to some extent offsets the negative effects of weather conditions.

Application of fertilizers in plant cultivation with row spacing of $60 \mathrm{~cm}$ - from $0.57 \mathrm{t} /$ ha to $0.72 \mathrm{t} / \mathrm{ha}$ has the greatest influence on swithgrass yield. Both increase and decrease of the width of row spacing leads to decrease of crop yield. Swithgrass yield depends on the height of the plants by $25 \%$ under the coefficient of correlation $r=0.51$ and by $23 \%-$ on the number of stems according to the correlation coefficient $r=0.48$.

Key words: switchgrass, quantitative indices of plants, yields, seeds, regularities. 